\title{
ANALISIS EPISTIMOLOGIS DAN PRINSIP-PRINSIP DASAR PEMBENTUKAN HUKUM ISLAM
}

\author{
Muhammad Yunan Putra \\ Institut Agama Islam (IAI) Muhammadiyah Bima \\ Jl. Anggrek No. 16 Ranggo Na'e Kota Bima \\ mohammed.elgehdy@gmail.com
}

\begin{abstract}
:
Human is to depend on the law; which it created by human self or God's firmness. The law is understand as the instrument control of human attitude to range between person and others, environment, their leader, nation, and God, even tough the property. In this context, the writer try to analyze the concept of epistemology and principle formulation of Islamic law, those, writer use library approach. Result of analyze shows that, Islamic Law in philosophy subjectively and it resource from value in Islamic concept. Meanwhile, in the side formulation law, Islamic law has the religion habitual in which the judge can take it to policy the problems as the low in social life. In this terms, it based on the theory in Islam such as; tauhid, judgment, amar makruf nahi mungkar, equal, at-ta'wun, and tolerance. Finally, Islamic Low can be resource of Positive Low which it to policy the problems in social life.
\end{abstract}

Keywords: Epistemology, Law, Principle of Islamic Law

\section{Pendahuluan}

\section{a. Latar Belakang}

Islam merupakan agama universal ${ }^{1}$, dan kompehensif $^{2}$. Ia hadir kepermukaan bumi untuk dijadikan pedoman hidup umat Islam³, baik

${ }^{1}$ Universal maksudnya al-aslah fi kulli zaman wal makan (sesuai dengan waktu dan tempat).

${ }^{2}$ Kompehensif maksudnya identik dengan makna yang terjandung dalam kalimat. "Ma Farratna fi al-kitab min sai"; "tidaklah Kami alpakan sesuatu dalam alkitab: (QS. Al-An'am: 38). Footnote al-Qur'an dan Terjemahnya. ... sebagian mufassir menafsirkan al-Qur'an dengan arti: dalam al-Qur'an itu telah ada pokok-pokok agama, norma-norma hokum hikmah-hikmah dan pimpinan untuk kebahagiaan manusia di dunia dan akhirat, dan kebahagiaan makhluk pada umumnya. Hasbi Ashshiddiqi, dkk. Al-Qur'an dan terjemahnya, (madinah Al-Munawwarat, mujma Khadim al-Haramain al-sarifain Malik Fahd, li Taba'at Mushaf al-Syarif, 1411 H). h. 192.

${ }^{3}$ QS. Al-Baqarah: 2. 
selaku individu, selaku komunitas kecil (masyarakat), maupun komunitas besar (bangsa); baik dalam konteks hubungan vertikal dengan Sang Pencipta ataupun dalam hubungan secara horizontal dengan sesama makhluk ciptaan-Nya, termasuk manusia. Relasi-relasi demikian telah dikonsepkan dalam Islam. ${ }^{4}$

Oleh karnanya secara teoritis, umat Islam meyakini bahwasannya hukum Islam merupakan sebuah takdir (destiny) dalam mengatur semua aspek kehidupan manusia karena Tuhan telah menunjukkan jalan yang lurus untuk dijadikan pedoman oleh manusia. Bentuknya yaitu dengan berpegang teguh pada apa yang diturunkan Allah dan mengikuti RasulNya. Hal ini antara lain disandarkan pada ayat-ayat alqur'an sebagai berikut:

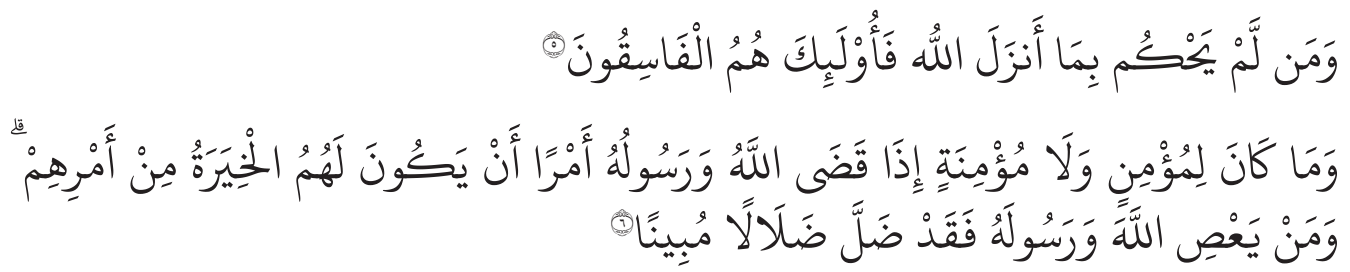

Namun yang menjadi permasalahan, ketika hukum Islam tersebut masuk ke dalam ranah demokrasi, dalam hal ini Indonesia misalnya. Negara Indonesia adalah salah satu Negara yang berdiri atas dasar domokrasi, warga Negara-pun terdiri dari beragai macam bentuk kepercayaan dan agama; sehingga sulit bagi Negara membentuk dan menetapkan hukum Islam diatasnya, kecuali membentuk hukum nasional; Sehingga hukum tersebut merata dan dapat di terima oleh berbagai kalangan yang hidup dan tinggal didalamnya. Berangkat dari kondisi tersebut, menurut penulis penting untuk memahami kembali gagasan konseptual tentang hokum Islam terutama dalam tinjauan epistimologis dan prinsip-prinsip dasar pembentukan hukum Islam.

\section{b. Rumusan Masalah}

Berdasarkan latar belakang yang dipaparkan di atas, maka masalah

${ }^{4}$ Munir Subarman, Hukum Islam dan Ketatanegaraan (Jakarta, Badan Litbang dan Diklat Kementerian Agama RI, 2012). H. 1

${ }^{5}$ QS. Al-an'am: 38 dan Al-Nahl: 89

${ }^{6}$ QS. Al-Anbiya': 107

Sangaji Jurnal Pemikiran Syariah dan Hukum 
pokok uraian tulisan ini dimaksudkan untuk mengetahui lebih lanjut mengenai pembentukan hukum Islam dalam sistem ilmu hukum (hukum Nasional), yang selanjutnya pokok permasalahan tersebut di tuangkan dalam sub masalah di bawah ini:

1. Analisis Epistemologi Hukum Islam

2. Prinsip-Prinsip Dasar Dalam Pembentukan Hukum Islam

\section{Pembahasan}

Islam sebagai agama yang dipeluk oleh mayoritas penduduk Indonesia, tentu sangat berpengaruh terhadap pola hidup bangsa Indonesia. Dalam pandangan masyarakat Indonesia, hukum Islam merupakan bagian penting dari ajaran agama, dan juga Islam merupakan ruangan ekspresi pengalaman agama yang utama dan menjadi terminan kontinyutas dan identitas historis. ${ }^{7}$

Demikian halnya hukum Islam di Indonesia, dalam formulasi yang sangat sederhana dapat dinyatakan bahwa pada hakikatnya hukum Islam di Indonesia adalah norma-norma hukum yang bersumber dari syariat Islam yang tumbuh dan berkembang dalam kehidupan masyarakat sepanjang bentangan sejarah Indonesia. Ia terlahir dari hasil perkawinan normatif (syari'ah) dengan muatan-muatan lokal Indonesia secara utuh. ${ }^{8}$

Berdasarkan teori ini, maka dapat dinyatakan bahwa keberadaan hukum Islam di Indonesia adalah bersamaan dengan keberadaan Islam di Indonesia. Oleh karena itu ketika masyarakat Indonesia menyatakan Islam (menyatakan dua kalimat syahadat), secara otomatis berarti mengakui otoritas hukum Islam atas dirinya. Inilah yang disebut dengan teori syahadat atau teori Kredo. ${ }^{9}$

Berdasarkan penelitian yang dilakukan oleh Fakultas Hukum

${ }^{7}$ Abdul Haris Abbas, Hukum Islam Dalam Hukum Nasional (Jurnal STAIN Ternate, Vol. 13 No. 1, 2013) h. 64

${ }^{8}$ Abd. Halim Barakatullah dan Teguh Prasetyo, Hukum Islam Menjawab Tantangan Zaman Yang Terus Berkembang (Cet.I; Yogyakarta, Pustaka Pelajar, 2006), h. 68

9 Teori kredo atau syahadat adalah teori yang mengharuskan pelaksanaan hukum Islam oleh mereka yang telah mengucapkan dua kalimat syahadat sebagai konsekuensi logis dari pengucapan kredonya. Teori ini berlaku di Indonesia ketika negeri ini berada di bawah kekuasaan para sultan, Lihat, Imam syaukani. Rekonstruksi Epistemologi Hukum Islam Indonesia dan Relevansinya Bagi Pembangunan Hukum Nasional (Cet. I; Jakarta: Raja GrafindoPersada, 2006), h. 68 
Universitas Indonesia, bekerja sama dengan Badan Pembinaan Hukum Nasional, pada tahun 1978 dan 1979 di empat belas daerah yang tersebar di seluruh Indonesia meliputi pulau Sumatera, Jawa, Kalimantan Selatan, dan Nusa Tengara Barat (Lima daerah pada tahun 1978 dan sembilan daerah pada tahun 1979) terlihat kecendrungan yang kuat di kalangan masyarakat untuk memberlakukan hukum Islam bagi Umat Islam. Delapan puluh persen $(80 \%)$ dari jumlah responden yang ditanyai menyatakan keinginan untuk diberlakukanya hukum Islam bagi mereka dari pada hukum yang lain ${ }^{10}$. Dengan demikian, sudah merupakan suatu keharusan untuk membentuk hukum nasional yang salah satu bahan bakunya bersumber dari hukum Islam.

\section{A. Hukum Islam}

Kata hukum Islam apabila dicari secara langsung dalam al-Qur'an, maka tidak ditemukan sama sekali dan begitu juga dalam literatur hukum Islam. Yang ada dalam al-Qur'an adalah kata syari'ah, fiqh, hukum Allah dan yang seakar dengannya. Kata-kata hukum Islam merupakan terjemahan dari term "Islamic Law" dari literatur Barat. ${ }^{11}$

Dalam penjelasan tentang hukum Islam dari literatur Barat ditemukan definisi hukum Islam yaitu: keseluruhan kitab Allah yang mengatur kehidupan setiap muslim dalam segala aspeknya ${ }^{12}$. Dari definisi ini arti hukum Islam lebih dekat dengan pengertian syariah.

Hasbi Asy-Syiddiqy memberikan definisi hukum Islam dengan "koleksi daya upaya fuqaha dalam menerapkan syari'at Islam sesuai dengan kebutuhan masyarakat"13. Pengertian hukum Islam dalam definisi ini mendekati kepada makna fiqh.

Untuk lebih memberikan kejelasan tentang arti hukum Islam, perlu diketahui lebih dahulu arti dari kata "hukum". Sebenarnya tidak ada arti yang sempurna tentang hukum. Namun, untuk mendekatkan

${ }^{10}$ Muhammad Daud Ali, Hukum Islam; Pengantar Ilmu Hukum dan Tata Hukum di Indonesia (Cet; III; Jakarta: Rajawali Pers, 1990), h. 239-240

${ }_{11}$ Mardani, Hukum Islam; Kumpulan Peraturan Tentang Hukum Islam di Indonesia (Cet.I, Jakarta, PT. Fajar Inter Pratama Mandiri) h. 9

${ }^{12}$ Mardani, Kedudukan Hukum Islam Dalam Sistem Hukum Nasional (Jurnal Fakultas Hukum Universitas Krisnadwipayana Jakarta No. 2, Vol. 16 2009) h. 270-272 h. 44

${ }^{13}$ Muhammad Hasbi Ash-Shiddiqy, Falsafah Hukum Islam, (Jakarta: Bulan Bintang, 1993),

Sangaji Jurnal Pemikiran Syariah dan Hukum 
kepada pengertian yang mudah dipahami, meski masih mengandung kelemahan, definisi yang diambil oleh Muhammad Muslehuddin dari Oxford English Dictionary perlu diungkapkan. Menurutnya, hukum adalah "the body of rules, wether proceeding from formal enactment or from custom, which a particular state or community recognizes as binding on its members or subjects". (Sekumpulan aturan, baik yang berasal dari aturan formal maupun adat, yang diakui oleh masyarakat dan bangsa tertentu sebagai mengikat bagi anggotanya). ${ }^{14}$

Bila hukum dihubungkan dengan Islam, maka hukum Islam berarti: "Seperangkat peraturan berdasarkan wahyu Allah dan Sunnah Rasul tentang tingkah laku manusia mukallaf yang diakui dan diyakini berlaku dan mengikat untuk semua umat yang beragama Islam". ${ }^{15}$ Dan dapat juga dikatakan bahwa hukum Islam yang dimaksudkan di sini yaitu hukum perdata Islam tertentu yang menjadi hukum positif bagi umat Islam, yang sekaligus merupakan hukum terapan bagi pengadilan agama. Dengan demikian hukum Islam mencakup hukum syari'at dan juga hukum fikih, karena arti syari'at dan fikih terkandung didalamnya. M. Rasyidi tampaknya menamakan hukum Islam sebagai hukum yang bersumber dari al-Qur'an, al-Sunnah dan akal. Menurut Abdul Wahab Khallaf hukum adalah khitab syari'iy yang bersangkutan dengan perbuatan orang-orang mukallaf secara perintah atau diperintah memilih atau berupa ketetapan (taqrir). ${ }^{16}$

Menurut LJ Van Apel Doorn ${ }^{17}$ adalah sangat sulit untuk mengadakan sesuai dengan kenyataan. Sehingga definisi yang dikemukakan oleh para ahli berbeda-beda dari segi redaksi dan unsur-unsurnya. Sebagai pegangan bagi orang yang sementara belajar hukum, maka pengertian hukum itu adalah: "Peraturan-peraturan yang bersifat memaksa yang menentukan tingkah laku manusia dalam lingkungan masyarakat yang

${ }^{14}$ AS. Honrby, Oxford Advanced Learner's Dictionary of Current English, (Britain: Oxford University Press, 1986), h. 478

${ }^{15}$ Amir Syarifuddin, "Pengertian dan Sumber Hukum Islam", dalam Falsafah Hukum Islam, (Jakarta: Bumi Aksara, 1992), h. 14

${ }^{16}$ Lihat; Abdul Wahab Khallaf, Ilmu Ushul Fiqhi, diterjemahkan oleh Moh. Noer Iskandar al-Barrsaniy dkk. Dengan judul Kaidah-kaidah Hukum Islam Ilmu Ushul Fighi, (Cet. II; Jakarta: Rajawali Perss, 1991)

17 Abd. Khalik Latuconsina, Pengembangan Hukum Islam "Suatu Kerangka Analisis Epistemologis" . jurnaltahkim.wordpress.com, dipulikasikan pada tanggal 2 bulan Mei 2009 
dibuat oleh badan-badan resmi berwajib, pelanggaran mana terhadap peraturan-peraturan tadi berakibatkan diambilnya tindakan-tindakan yaitu dengan hukum tertentu."Dari pengertian ini dapatlah disimpulkan bahwa hukum itu harus mempunyai unsur-unsur seperti berikut:

$\checkmark$ Peraturan tentang tingakh laku manusia dalam pergaulan masyarakat.

$\checkmark \quad$ Peraturan itu dilakukan oleh badan-badan resmi yang berwajib.

$\checkmark$ Peraturan itu bersifat memaksa.

$\checkmark$ Sanksi terhadap pelanggaran peraturan tersebut adalah tegas.

\section{B. Analisis Epistemologis}

Sebagai bagian dari sistem hukum, maka ilmu hukum dibicarakan sebagai penjabaran, pemujian dan pengembangan teori-teori hukum yang berasal dari komponen filsafat hukum. Tujuan penjabaran dan perkembangan itu berkaitan erat dengan dimensi-dimensi utama ilmu hukum yaitu dimensi epistemologi dan akisologinya. Dalam topik ini lebih difokuskan pada analisis epistemologis, namun dalam setiap jenis pengetahuan mempunyai ciri spesifik mengenal apa (ontologi) bagaimana (epistemologi) dan untuk apa (aksiologi) pengetahuan tersebut disusun. Kalau kita ingin membicarakan epistemologi ilmu, maka ia harus dikaitkan dengan ontologi ilmu dan aksiologi ilmu.

Antara hukum Islam dan ilmu hukum memiliki orientasi dan objek kajian yang sama yaitu tentang tingkah laku manusia. Selain itu, hukum Islam mengatur hubungan sepihak dengan Tuhan dalam bentuk perintah dan larangan. Hukum Islam sebagai sistem hukum memiliki komponenkomponen sebagaimana komponen sistem hukum yang terdiri atas masyarakat hukum, budaya hukum, filsafat hukum, pendidikan hukum, konsep hukum, pembentukan hukum, bentuk hukum, penerapan hukum, evaluasi hukum dan masyarakat hukum. ${ }^{18}$

Masyarakat Indonesia yang mayoritas memeluk agama Islam memenuhi syarat untuk penerapan hukum Islam. Dari segi budaya hukum, masyarakat Indonesia telah memiliki hukum tertulis walaupun sifatnya masih terbatas, seperti berlakunya Undang-Undang no. 7 tahun

${ }^{18}$ Bustanul Arifin, Perkembangan hukum Islam di Indonesia Akar Sejarah, Hambatan dan Prospeknya, (Cet. I; Jakarta: Gema Insani Press, 1996) h. 34

Sangaji Jurnal Pemikiran Syariah dan Hukum 
1989 tentang Peradilan Agama, INPRES no. 1 tahun 19081 tentang Kompilasi Hukum Islam, PP no. 28 tahun 1977 tentang Wakaf Tanah Milik dan sebagainya. ${ }^{19}$

Pada sisi filsafat hukumnya, hukum Islam adalah filsafat hukum yang bersifat subjektif dan berasal dan dianut oleh masyarakat Islam yang berkaitan dengan nilai-nilai Islam konsep-konsep hukum Islam. Dari segi konsep, hukum Islam memilki sumber ajaran yaitu al-Qur'an, alSunnah dan Ijma' yang diformulasikan dalam bentuk fikih, fatwa ulama, keputusan pengadilan dan Undang-Undang. ${ }^{20}$ Dari segi pembentukan hukum, hukum Islam memiliki tradisi-tardisi atau kebiasaan keagamaan yang telah mendarah daging dalam masyarakat yang dapat diterapkan oleh hakim dalam memutuskan perkara-perkara hukum sebagai hukum yang hidup dalam masyarakat. Selain itu konsep-konsep hukum dapat terbentuk melalui badan legislatif sebagai terbentuknya UndangUndang no. 7 Tahun 1989. Dalam bidang evaluasi hukum baik buruknya pelaksanaan hukum Islam tergantung dari kualitas hukum Islam. Perbedaan pendapat memang ada dalam masalah hukum, tetapi sebatas pada konsep. Sedangkan pada penerapannya melalui perundangundangan telah nampak sejalan. ${ }^{21}$

Pembentukan hukum Islam di Indonesia erat kaitannya dengan faktor historis yang diwariskan kerajaan Islam di nusantara sebelum datangnya VOC dengan munculnya dua teori perkembangan hukum Islam, yaitu penerimaan hukum Islam sebagai sumber persuasif yakni hukum Islam al-Qur'an dan al-Sunnah. Penerimaan itu tertuang dalam Piagam Jakarta yang ditanda tangani tanggal 22 Juni 1945 yang berlangsung sampai tanggal 5 Juli 1959. Penerimaan hukum Islam sebagai sumber autoritif yakni sumber hukum yang telah dianut oleh semua imam mazhab. Hukum Islam menyatakan bahwa siapa pun yang telah menyatakan dirinya sebagai seorang muslim dengan mengucapkan kalimat syahadat, ia terikat untuk patuh dan taat kepada hukum ajaran Islam. Penerimaan itu tertuang dalam dekrit Presiden RI tanggal 5 Juli

${ }^{19}$ Ibid., h. 35

${ }^{20}$ Fathurrahman Djamil, Filsafat Hukum Islam, (Cet. I; Jakarta: Logos Wacana Ilmu, 1997) h. 126

${ }^{21}$ Ibid., h. 128 
1959 yang menyatakan bahwa Piagam Jakarta tanggal 22 Juni 1945 menjiwai UUD 1945 dan adalah merupakan suatu rangkaian kesatuan dalam konstitusi. ${ }^{22}$

Dalam perkembangan selanjutnya, munculnya teori "receptio in complexu" oleh L.W.C. Van Der Berg yaitu orang-orang muslim Indonesia menerima syri'at secara keseluruhan. Teori ini mendapat tantangan dari C. Van Vollenhopen dan C. Snouck Hurgronye dengan teori "receptio" yaitu hukum Islam berlaku setelah diresepsi oleh hukum adat. Kemudian Hazairin menantangnya dengan teori "receptio exit". Teori ini selanjutnya dikembangkan oleh Sayuti Thalib dengan teori "receptio a contrario" yang menyatakan bahwa hukum yang berlaku bagi rakyat Indonesia adalah hukum agamanya yang berarti hukum adat hanya berlaku kalau tidak bertentangan dengan hukum agama. ${ }^{23}$

Dari segi psikologis bangsa Indonesia penganut agama Islam mayoritas sehingga aturan yang ditetapkan tidak terlepas dari nilai-nilai ajaran Islam. Dari segi yuridis hukum Islam di Indonesia sangat kuat dan legal kedudukannya, walaupun materi hukum Islam masih terbatas pada masalah al-Ahkam al-Ahwal al-Syakhsiyah. Pembatasan materi tersebut sangat terkait dengan faktor historis yang dimainkan oleh pemerintah Hindia Belanda dan berlanjut hingga sekarang yang tidak menghendaki diberlakukannya hukum Islam di Indonesia. ${ }^{24}$

Lembaga-lembaga Islam yang diatur secara yuridis memilki kekuatan hukum berlaku di Indonesia, antara lain lahirnya Departemen Agama tanggal 3 Januari 1946, lahirnya Peradilan Agama bulan maret 1946 dengan nama Mahkamah Islam Tinggi dan kemandiriannya berdasarkan Undang-Undang no. 7 tahun 1989, terbentuknya Majelis Ulama Indonesia tanggal 26 Juli 1971. Negara Indonesia mengenal dua hukum dasar, yaitu yang tertulis dan yang tidak tertulis dimana yang pertama lebih utama dari yang kedua. ${ }^{25}$

Untuk mengukur apakah ada hukum Islam sebagai sistem hukum, Lon L. Fuller mengemukakan delapan asas yang dinamakan principle of

${ }_{22}^{2}$ Bustanul Arifin, Perkembangan hukum Islam di Indonesia Akar Sejarah, Hambatan dan Prospeknya. h. 86

${ }^{23}$ Ibid., h. 87

${ }^{24}$ Ibid.. h. 96

${ }^{25}$ Ibid., h. 98

Sangaji Jurnal Pemikiran Syariah dan Hukum 
legality yaitu: ${ }^{26}$

$\checkmark \quad$ Suatu sistem hukum harus mengadung peraturan yang tidak bersifat ad hoc. Dari landasan yuridis yang telah dikemukakan seluruh aturan-aturan hukum Islam tidak bersifat sementara.

$\checkmark$ Peraturan-peraturan yang telah dibuat itu harus diumumkan.

$\checkmark \quad$ Tidak boleh ada peraturan berlaku surut tetapi ditujukan berlakunya waktu yang akan datang.

$\checkmark$ Peraturan-peraturan hukum disusun dalam rumusan yang bisa dimengerti.

$\checkmark \quad$ Suatu sistem tidak boleh mengandung peraturan-peraturan yang bertentangan sama lain.

$\checkmark$ Peraturan tidak mengandung tuntunan yang melebihi apa yang dapat dilakukan.

$\checkmark$ Tidak boleh ada kebiasaan mengubah-ubah peraturan sehingga menyebabkan seseorang akan kehilangan orientasi.

$\checkmark$ Harus ada kecocokan peraturan yang diundangkan dengan pelaksanaan sehari-hari.

Kriteria-kriteria tersebut sejalan dan tidak bertentangan dengan peraturan-peraturan yang berkaitan dengan hukum Islam. Dari sisi aksiologinya, Hukum Islam sebagai hukum yang bersumber dari ajaran agama, tentu saja tujuan penerapannya agar memelihara kemaslahatan manusia, sekaligus untuk menghindari mafsadat, baik di dunia maupun di akhirat. Kemaslahatan yang menjadi tujuan syari'at dapat diurut sebagai berikut: ${ }^{27}$

$\checkmark$ Memelihara agama

$\checkmark$ Memelihara jiwa

$\checkmark$ Memelihara akal

$\checkmark$ Memelihara keturunan

$\checkmark$ Memelihara harta benda

Dalam pada itu, maksud penerapan hukum Islam diarahkan sebagai: ${ }^{28}$

\footnotetext{
${ }^{26}$ Juhaya S Praja. dan Eddi Rudiana Arif, At. Al, Hukum Islam di Indonesia, Pemikiran dan Praktek, (Bandung; PT. Raja Rosdakarya, 1994) h. 53

${ }^{27}$ Ibid., h. 54

${ }^{28}$ Ibid., h. 55-56
} 
$\checkmark \quad$ Sebagai sarana kontrol sosial, yakni mencegah umat manusia untuk melakukan pelanggaran hukum, baik yang bersifat pribadi maupun yang bersifat umum.

$\checkmark \quad$ Sebagai pembinaan moral masyarakat. Olehnya dalam masyarakat Islam, hukum bukan hanya faktor utama tapi juga faktor pokok, sehingga masyarakat Islam secara ideal harus berjalan sesuai dengan prinsip-prinsip moralitas Islam.

$\checkmark \quad$ Sebagai benteng pertahanan untuk menagkal identitas keislaman dari pengaruh non muslim dan terutama yang bersifat sekuler. Gambaran-gambaran seperti ini sering terlihat pada sidang DPR dalam membahas rancangan berbagai peraturan yang mengatur nilai-nilai Islam.

$\checkmark$ Mewujudkan ketentraman masyarakat sebagai individu ataupun kelompok.

\section{Prinsip-Prinsip Dasar Dalam Pembentukan Hukum Islam}

Sebagaimana hukum-hukum lain, hukum Islam memiliki prinsipprinsip dan asas-asas sebagai tiang pokok, kuat atau lemahnya sebuah undang-undang, mudah atau sukarnya, ditolak atau diterimanya oleh masyarakat, tergantung kepada asas dan tiang pokok tersebut. ${ }^{29}$

Secara etimologi (tata bahasa) prinsip adalah dasar, permulaan, aturan pokok. Juhaya S. Praja memberikan pengertian prinsip sebagai berikut: permulaan; tempat pemberangkatan; titik tolak; atau al-mabda. ${ }^{30}$ Dalam konteks terminologi, prinsip adalah kebeneran universal yang inheren didalam hukum Islam dan menjadi titik tolak pembinaannya; prinsip yang membentuk hukum dan setiap cabang-cabangnya. Prinsip hukum Islam meliputi prinsip umum dan prinsip umum. Prinsip umum ialah prinsip keseluruhan hukum Islam yang bersifat unuversal. Adapun prinsip-prinsip khusus ialah prinsip-prinsip setiap cabang hukum Islam. Prinsip-prinsip hukum Islam menurut Juhaya S. Praja sebagai berikut ${ }^{31}$ :

${ }^{29}$ M. Hasbi Ash-Shiddiqieqy, Falsafah Hukum Islam, (Cet-V, Jakarta, Bulan Bintang, 1993) h.

${ }^{30}$ Juhaya S. Praja, Filsafat Hukum Islam, (LPPM Unisba, Bandung, 1995) h. 69

${ }^{31}$ Ibid., h. 69-71

Sangaji Jurnal Pemikiran Syariah dan Hukum 


\section{Prinsip Tauhid}

Tauhid adalah prinsip umum hukum Islam. Prinsip ini menyatakan bahwa semua manusia ada dibawah satu ketetapan yang sama, yaitu ketetapan tauhid yang dinyatakan dalam kalimat La'ilaha Illa Allah (Tidak ada tuhan selain Allah). Prinsip ini ditarik dari firman Allah QS. Ali Imran: 64. Berdasarkan atas prinsip tauhid ini, maka pelaksanaan hukum Islam merupakan ibadah. Dalam arti perhambaan manusia dan penyerahan dirinya kepada Allah sebagai manipestasikesyukuran kepada-Nya. Dengan demikian tidak boleh terjadi setiap mentuhankan sesama manusia dan atau sesama makhluk lainnya. Pelaksanaan hukum Islam adalah ibadah dan penyerahan diri manusia kepada keseluruhan kehendak-Nya.

Prinsip tauhid inipun menghendaki dan memposisikan untuk menetapkan hukum sesuai dengan apa yang diturunkan Allah (AlQur'an dan As-Sunah). "Barang siapa yang tidak menghukumi dengan hukum Allah, maka orang tersebut dapat dikateegorikan kedalam kelompok orang-orang yang kafir, dzalim dan fasiq" (QS. Al-Maidah: 44, 45 dan 47).

Dari prinsip umum tauhid ini, maka lahirlah prinsip khusus yang merupakan kelanjutan dari prinsip tauhid ini, umpamanya yang berlaku dalam fiqih ibadah sebagai berikut:

$\checkmark$ Prinsip Pertama: Berhubungan langsung dengan Allah tanpa perantara. Artinya bahwa tak seorang-pun manusia dapat menjadikan dirinya sebagai zat yang wajib di sembah.

$\checkmark \quad$ Prinsip Kedua: Beban hukum (takli'f) ditujukan untuk memelihara akidah dan iman, penyucian jiwa (tazkiyat al-nafs) dan pembentukan pribadi yang luhur. Artinya hamba Allah dibebani ibadah sebagai bentuk/aktualisasi dari rasa syukur atas nikmat Allah.

Berdasarkan prinsip tauhid ini melahirkan azas hukum Ibadah, yaitu Asas kemudahan/meniadakan kesulitan. Dari asas hukum tersebut terumuskan kaidah-kaidah hukum ibadah sebagai berikut:

Al-ashlu fii al-ibadati tuqifu wal ittiba'; yaitu pada pokoknya ibadah itu tidak wajib dilaksanakan, dan pelaksanaan ibadah itu hanya mengikuti apa saja yang diperintahkan Allah dan Rasul-Nya. 
Al-masaqqah tujlibu at-taysir; Kesulitan dalam melaksanakan ibadah akan mendatangkan kemudahan

\section{Prinsip Keadilan}

Keadilan dalam bahasa Salaf adalah sinonim al-mizan (keseimbangan/ moderasi). Kata keadilan dalam al-Qur'an kadang diekuifalensikan dengan al-qist. Al-mizan yang berarti keadilan di dalam Al-Qur'an terdapat dalam QS. Al-Syura: 17 dan Al-Hadid: 25.

Term "keadilan" pada umumnya berkonotasi dalam penetapan hukum atau kebijaksanaan raja. Akan tetapi, keadilan dalam hukum Islam meliputi berbagai aspek. Prinsip keadilan ketika dimaknai sebagai prinsip moderasi, menurut Wahbah Az-Zuhaili bahwa perintah Allah ditujukan bukan karena esensinya, seba Allah tidak mendapat keuntungan dari ketaatan dan tidak pula mendapatkan kemadaratan dari perbuatan maksiat manusia. Namun ketaatan tersebut hanyalah sebagai jalan untuk memperluas prilaku dan cara pendidikan yang dapat membawa kebaikan bagi individu dan masyarakat.

Penggunaan term "adil/keadilan" dalam Al-Quran diantaranya sebagai berikut:

$\checkmark$ QS. Al-Maidah: 8 "Manusia yang memiliki kecenderungan mengikuti hawa nafsu, adanya kecintan dan kebencian memungkinkan manusia tidak bertindak adil dan mendahulukan kebatilan daripada kebenaran (dalam bersaksi)"

$\checkmark$ QS. Al-An'am: 152 "Perintah kepada manusia agar berlaku adil dalam segala hal terutama kepada mereka yang mempunyai kekuasaan atau yang berhubungan dengan kekuasaan dan dalam bermuamalah/berdagang"

$\checkmark$ QS. An-Nisa: 128; "Kemestian berlaku adil kepada sesama istri."

$\checkmark$ QS. Al-Hujurat: 9; "Keadilan sesama muslim."

$\checkmark$ QS. Al-An'am:52; “Keadilan yang berarti keseimbangan antara kewajiban yang harus dipenuhi manusia (mukalaf) dengan kemampuan manusia untuk menunaikan kewajiban tersebut."

Dari prinsip keadilan ini lahir kaidah yang menyatakan hukum Islam dalam praktiknya dapat berbuat sesuai dengan ruang dan waktu, yakni suatu kaidah yang menyatakan elastisitas hukum Islam dan kemudahan dalam melaksanakannya sebagai kelanjutan dari prinsip keadilan, yang

Sangaji Jurnal Pemikiran Syariah dan Hukum 
artinya:

"Perkara-perkara dalam hukum Islam apabila telah menyeempit maka menjadi luas; apabila perkara-perkara itu telah meluas maka kembali menyempit."

Teori “keadilan" teologi Mu'tazilah melahirkan dua terori turunan, yaitu:

$\checkmark$ al-salah wa al-aslah dan

$\checkmark$ al-Husna wa al-qubh.

Dari kedua teori ini dikembangkan menjadi pernyataan sebagai berikut :

$\checkmark$ Pernyataan Pertama: Allah tidaklah berbuat sesuatu tanpa hikmah dan tujuan" perbuatan tanpa tujuan dan hikmah adalah sia-sia

$\checkmark$ Pernyataan Kedua: Segala sesuatu dan perbuatan itu mempunyai nilai subjektif sehingga dalam perbuatan baik terdapat sifat-sifat yang menjadi perbuatan baik. Demikian halnya dalam perbuatan buruk. Sifat-sifat itu dapat diketahui oleh akal sehingga masalah baik dan buruk adalah masalah akal.

\section{Prinsip Amar Makruf Nahi Mungkar}

Hukum Islam digerakkan untuk merekayasa umat manusia untuk menuju tujuan yang baik dan benar yang dikehendaki dan ridloi Allah dalam filsafat hukum Barat diartikan sebagai fungsi social engineering hukum. Prinsip Amar Makruf Nahi Mungkar didasarkan pada QS. AlImran: 110, pengkategorian Amar Makruf Nahi Mungkar dinyatakan berdasarkan wahyu dan akal.

\section{Prinsip Kebebasan/Kemerdekaan}

Prinsip kebebasan dalam hukum Islam menghendaki agar agama/ hukum Islam disiarkan tidak berdasarkan paksaan, tetapi berdasarkan penjelasan, demontrasi, argumentasi. Kebebasan yang menjadi prinsip hukum Islam adalah kebebasan dl arti luasyg mencakup berbagai macamnya, baik kebebasan individu maupun kebebasan komunal. Keberagama dalam Islam dijamin berdasarkan prinsip tidak ada paksaan dalam beragama (QS. Al-Baqarah: 256 dan Al-Kafirun: 5) 


\section{Prinsip Persamaan/Egalite}

Prinsip persamaan yang paling nyata terdapat dalam Konstitusi Madinah (al-Shahifah), yakni prinsip Islam menentang perbudakan dan penghisapan darah manusia atas manusia. Prinsip persamaan ini merupakan bagian penting dalam pembinaan dan pengembangan hukum Islam dalam menggerakkan dan mengontrol sosial, tapi bukan berarti tidak pula mengenal stratifikasi sosial seperti komunis.

\section{Prinsip At-Ta'awun}

Prinsip ini memiliki makna saling membantu antar sesama manusia yang diarahkan sesuai prinsip tauhid, terutama dalam peningkatan kebaikan dan ketakwaan.

\section{Prinsip Toleransi}

Prinsip toleransi yang dikehendaki Islam adalah toleransi yang menjamin tidak terlanggarnya hak-hak Islam dan ummatnya, tegasnya toleransi hanya dapat diterima apabila tidak merugikan agama Islam.

Wahbah Az-Zuhaili, memaknai prinsip toleransi tersebut pada tataran penerapan ketentuan Al-Qur'an dan Hadits yang menghindari kesempitan dan kesulitan, sehingga seseorang tidak mempunyai alasan dan jalan untuk meninggalkan syari'at ketentuan hukum Islam. Dan lingkup toleransi tersebut tidak hanya pada persoalan ibadah saja tetapi mencakup seluruh ketentuan hukum Islam, baik muamalah sipil, hukum pidana, ketetapan peradilan dan lain sebagainya. ${ }^{32}$

\section{Kesimpulan}

Dari uraian di atas dapat disimpulkan bahwa, hukum Islam secara teoritis telah memenuhi syarat menurut pandangan korelasi sistem hukum sesuai komponen-komponen sistem hukum. Dilihat dari segi historisnya, hukum Islam telah melalui proses sejarah yang panjang dengan segala pasang surutnya yang dipotong oleh teori syahadat, teori receptio in comlexu, teori receptio, teori receptio exit dan teori receptio a h.30

${ }^{32}$ Wahbah Az-Zuhaili, Al-Dharuurah Al-Syar'iyyah, (Muasasah al-Risalah, Damaskus, tth)

Sangaji Jurnal Pemikiran Syariah dan Hukum 
contrario. Secara yuridis telah memenuhi syarat sebagai sistem hukum karena telah memilki berbagai peraturan perundang-undangan, meskipun terbatas pada al-Ahkām al-Ahwāl al-Syakshiyah. Sedangkan dari segi psikologis bahwa umat Islam Indonesia yang mayoritas senantiasa menjadi pertimbangan utama dalam penerapan hukum di Indonesia.

\section{Daftar Pustaka}

Ali, Muhammad Daud, Hukum Islam; Pengantar Ilmu Hukum dan Tata Hukum di Indonesia, Cet; III; Jakarta: Rajawali Pers, 1990

Mardani, Kedudukan Hukum Islam Dalam Sistem Hukum Nasional, Jurnal Fakultas Hukum Universitas Krisnadwipayana Jakarta No. 2, Vol. 162009

Hukum Islam; Kumpulan Peraturan Tentang Hukum Islam di Indonesia, Cet.I, Jakarta, PT. Fajar Inter Pratama Mandiri, Tth.

Ash-Shiddiqy, Muhammad Hasbi , Falsafah Hukum Islam, Jakarta: Bulan Bintang, 1993

AS. Honrby, Oxford Advanced Learner's Dictionary of Current English, Britain: Oxford University Press, 1986

Syarifuddin, Amir, "Pengertian dan Sumber Hukum Islam", dalam Falsafah Hukum Islam, Jakarta: Bumi Aksara, 1992

Khallaf, Abdul Wahab, Ilmu Ushul Fighi, diterjemahkan oleh Moh. Noer Iskandar al-Barrsaniy dkk. Dengan judul Kaidah-kaidah Hukum Islam Ilmu Ushul Fiqhi, Cet. II; Jakarta: Rajawali Perss, 1991

Latuconsina, Abd. Khalik, Pengembangan Hukum Islam "Suatu Kerangka Analisis Epistemologis" . jurnaltahkim.wordpress.com, dipulikasikan pada tanggal 2 bulan Mei 2009

Az-Zuhaili, Wahbah, Al-Dharuurah Al-Syar'iyyah, (Muasasah al-Risalah, Damaskus, tth

Arifin Bustanul, Perkembangan hukum Islam di Indonesia Akar Sejarah, Hambatan dan Prospeknya, Cet. I; Jakarta: Gema Insani Press, 1996

Djamil, H. Fathurrahman, Filsafat Hukum Islam, Cet. I; Jakarta: Logos Wacana Ilmu, 1997

Praja, Juhaya. S. dan Eddi Rudiana Arif, At. Al, Hukum Islam di Indonesia, Pemikiran dan Pratek, Bandung; PT. Raja Rosdakarya, 1994 